\title{
Validation of high performance liquid chromatographic and spectrophotometric methods for the determination of the antiparkinson agent pramipexole dihydrochloride monohydrate in pharmaceutical products
}

\author{
Serpil Sevim ${ }^{1,2, *}$, Nevin Erk $^{1}$ \\ ${ }^{1}$ Department of Analytical Chemistry, Faculty of Pharmacy, Ankara University, Ankara, Turkey, ${ }^{2}$ Dinçsa Pharmaceutical \\ Industry and Trade Inc., Organize Sanayi Bölgesi, Ankara, Turkey
}

\begin{abstract}
The antiparkinson agent pramipexole dihydrochloride monohydrate was quantified in pharmaceutical products by high performance liquid chromatography (HPLC) and derivative spectrophotometry. The first method was based on $\mathrm{HPLC}$ using tamsulosin $\mathrm{HCl}$ as an internal standard. In this method, chromatographic separation was achieved using a LiChrospher $60 \mathrm{RP}$ column at $25^{\circ} \mathrm{C}$, with a flow rate of $1.0 \mathrm{~mL} / \mathrm{min}$ at $263 \mathrm{~nm}$. The eluent comprised $0.01 \mathrm{~mol} / \mathrm{L}$ ammonium acetate $(\mathrm{pH} 4.4)$ and acetonitrile ( $35: 65$ by volume). The linearity range was found to be $10.0-30.0 \mu \mathrm{g} / \mathrm{mL}$ with a mean recovery of $100.5 \pm 1.10$. The limit of detection $(8 \mathrm{ng} / \mathrm{mL})$ and limit of quantification $(50 \mathrm{ng} / \mathrm{mL})$ were calculated. In the second method, the first derivative spectrophotometric technique for the determination of pramipexole dihydrochloride monohydrate was performed by measuring the amplitude at 249 and $280 \mathrm{~nm}$. In the first derivative technique, the absorbance and concentration plot was rectilinear over the $5.0-35.0 \mu \mathrm{g} / \mathrm{mL}$ range with a lower detection limit of $1.5 \mathrm{ng} / \mathrm{mL}$ and quantification limit of $4.5 \mathrm{ng} / \mathrm{mL}$. The typical excipients included in the pharmaceutical product do not interfere with the selectivity of either method. The developed methods were validated for robustness, selectivity, specificity, linearity, precision, and accuracy as per the ICH and FDA guidelines (ICH Q2B, 1996; FDA,2000). In conclusion, the developed methods were successful in determining the quantity of the antiparkinson agent pramipexole dihydrochloride monohydrate in pharmaceutical products. The RSD values for the pharmaceutical product used in this study were found to be $0.97 \%$ for the HPLC method and $0.00 \%$ for the first derivative spectrophotometric method.
\end{abstract}

Uniterms: Antiparkinson agent/determinação. Pramipexole dihydrochloride monohydrate. Pharmaceutical product/quality control. High performance liquid chromatography/quantitative analysis. Derivative spectrophotometry/quantitative analysis.

O fármaco antiparkinsoniano, dicloridrato de pramipexol monoidratado, foi quantificado no produto farmacêutico por cromatografia líquida de alta eficiência (CLAE) e espectrofotometria derivada. No primeiro método baseado na CLAE, o cloridrato de tansulosina foi usado como padrão interno. Nesse método, a separação cromatográfica foi realizada usando uma coluna Lichrosper $60 \mathrm{RP}$ a $25{ }^{\circ} \mathrm{C}$ e acetato de amônio 0,01 mol/L (pH:4.4): acetonitrila (35:65 em volume) como eluente com fluxo de 1,0 $\mathrm{mL} / \mathrm{min}$ a $263 \mathrm{~nm}$. A faixa de linearidade foi de $10.0-30.0 \mu \mathrm{g} / \mathrm{mL}$ com média da recuperação 100.5 \pm 1.10 . O limite de detecção $(8 \mathrm{ng} / \mathrm{mL})$ e o limite de quantificação $(50 \mathrm{ng} / \mathrm{mL})$ foram calculados. Por outro lado, a primeira técnica de espectrofotometria derivada para a determinação de dicloridrato de pramipexol monoidratado foi realizada através da medida da amplitude a 249 e $280 \mathrm{~nm}$. Na técnia da primeira derivada, a absorvância e a plotagem da concentração foi retilínea na faixa de 5.0-35.0 $\mu \mathrm{g} / \mathrm{mL}$ com limite inferior de deteç̧ão de $1.5 \mathrm{ng} / \mathrm{mL}$ e limite de quantificação de $4.5 \mathrm{ng} / \mathrm{mL}$. Os excipientes típicos incluídos no produto farmacêutico não interferem com a seletividade dos métodos. Os métodos desenvolvidos foram validados quanto à robustez, seletividade, especificidade, linearidade, precisão e

*Correspondence: S. Sevim. Department of Analytical Chemistry. Faculty of Pharmacy. Ankara University 06100. Ankara-Turkey. E-mail: uretim@dincsa.com 
exatidão de acordo com as diretrizes do ICH e FDA(ICH Q2B,1996; FDA,2000). Concluindo, os métodos propostos foram aplicados com sucesso para a determinação quantitativa do agente antiparkinsoniano dicloridrato de pramipexol monoidrato em produtos farmacêuticos. Os valores de RSD para o produto farmacêutico utilizado neste estudo foi $0.97 \%$ para a CLAE e $0.00 \%$ para o método de espectrofotometria de primeira derivada.

Unitermos: Agente antiparkinsoniano/determinação. Dicloridrato de pramipexol monoidrato. Produto farmacêutico/controle de qualidade. Cromatografia líquida de alta eficiência/análise quantitativa. Espectrofotometria derivada/análise quantitativa.

\section{INTRODUCTION}

The chemical name of pramipexole dihydrochloride monohydrate is (6S)-6- $N$-propyl-4,5,6,7-tetrahydro-1,3benzothiazole-2,6-diamine dihydrochloride monohydrate (Figure 1). The structural formula is given below (O'Neil et al., 2006).

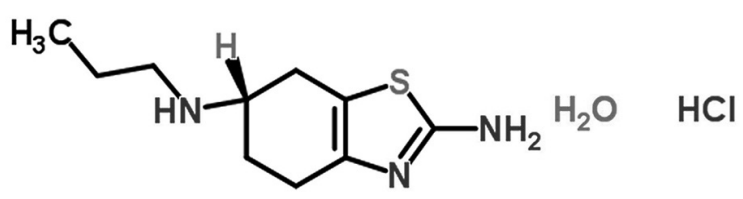

FIGURE 1 - Structure of pramipexole dihydrochloride monohydrate.

Pramipexole is a non-ergot dopamine agonist. Pramipexole alleviates parkinsonian motor deficits by stimulation of dopamine receptors in the striatum. It may be used as monotherapy or in combination with levodopa. Pramipexole is indicated for the treatment of the signs and symptoms of idiopathic Parkinson's disease and the symptomatic treatment of idiopathic Restless Legs Syndrome (Physicians' Desk Reference, 2013).

Many analytical methods for the measurement of pramipexole in pharmaceutical dosage forms or biological fluids have been reported. Those methods are based on spectrophotometry (Armağan, 2011; Babu, Raju, 2007; El-Bayoumi, 2009; Gurupadayya, Vishwajith, Srujana, 2009; Rani, Reddy, 2006; Rani, Reddy, 2007; Thangabalan et al., 2011a,b), high-performance liquid chromatography (HPLC) (El-Sherif, Abdel-Fattah, El-Houssini, 2008; Hua et al., 2011; Jancic et al., 2007a,b; Kamienska-Duda, Kosmacinska, 2008; Malenovic et al., 2010; Manish et al., 2010; Ramakrishna et al., 2007; Rao et al., 2009; Shuhui, 2010; Srinubabu et al., 2006; Syeda et al., 2010; Vijaya et al., 2009), gas chromatography (Panchal, Patel, Menon, 2011), and capillary electrophoresis (Musenga et al., 2008; Chang-Hai et al., 2009).

Easy, rapid, and economical analytical methods are desirable in order to achieve routine quality control testing of drugs. The objective of the present study was to develop and validate a new simple, efficient, selective, precise, and reproducible method for routine quality control analyses of commercial pharmaceutical dosage forms containing pramipexole. Both HPLC and the spectrophotometric methods have been widely applied because they sensitive, reproducible, and precise.

\section{EXPERIMENTAL}

\section{Chemicals}

The pramipexole dihydrochloride monohydrate standard sample was provided by Orchid Chemicals and Pharmaceuticals Ltd (Maharashtra, India) and the internal standard (IS), tamsulosin $\mathrm{HCl}$, was obtained from Titan Laboratories Pvt Ltd (Maharashtra, India). Acetonitrile, glacial acetic acid $100 \%$, ammonium acetate EMSURE ${ }^{\circledR}$ ACS Reagent, and HPLC-grade water were supplied from J.T. Baker (Deventer, Netherlands). The HCl 37\% ACS reagent was obtained from Merck (Darmstadt, Germany). All other reagents were of analytical grade, and were used as received.

\section{Instrumentation and analytical conditions}

The HPLC system consisted of a membrane degasser, a quartet gradient pump, a $100 \mu \mathrm{L}$ cyclic injection valve, an autosampler with 100 vials, and a UV/Vis detector (1200 Series, Agilent Technologies, USA). A reversed phase Merck brand LiChrospher 60 RP-Select B (125 x $4.0 \mathrm{~mm}, 5 \mu \mathrm{m})$ column was used. The mobile phase was composed of $0.01 \mathrm{~mol} / \mathrm{L}$ ammonium acetate ( $\mathrm{pH} 4.4)$ and acetonitrile ( $35: 65$ by volume). The solution was filtered through a $0.20 \mu \mathrm{m}$ membrane filter and degassed by sonication before use. The flow rate was $1.0 \mathrm{~mL} / \mathrm{min}$, the column temperature was $25^{\circ} \mathrm{C}$, the detector wavelength was set at $263 \mathrm{~nm}$, and the injection volume was $20.0 \mu \mathrm{L}$. The peak areas were integrated automatically with Windows NT based LC ChemStation Software. 
The spectrophotometric analysis was performed using a Shimadzu UV-1601 UV/Visible double beam spectrophotometer. The cells used for absorbance measurements were $10 \mathrm{~mm}$ path length quartz cells. Derivative conditions were as follows: scan speed, $60.0 \mathrm{~nm} / \mathrm{min}$; spectral slit width, $2.0 \mathrm{~nm} ; \Delta \lambda, 6.0 \mathrm{~nm}$.

\section{Development of the HPLC and spectrophotometric methods}

During the development of the HPLC method, the appropriate diluent and internal standard were first chosen. Pramipexole dihydrochloride monohydrate was best dissolved in water, and it was established visually that water was also the best diluent for the internal standard tamsulosin $\mathrm{HCl}$.

After evaluating different columns, the most appropriate one was chosen. During this process, it was observed that the RP8, C8, and C18 columns did not show resolution of the pramipexole dihydrochloride monohydrate and internal standard peaks. The best resolution was achieved using the RP-Select B column.

Different mobile phases were tried and the mobile phase that showed the best peak performance was chosen. When a 25:75 volume ratio of $0.01 \mathrm{~mol} / \mathrm{L}$ ammonium acetate $(\mathrm{pH} 4.4)$ and acetonitrile was used as the mobile phase, the resolution achieved was low and the internal standard and pramipexole peaks were close to each other. When a 50:50 volume ratio of $0.01 \mathrm{~mol} / \mathrm{L}$ ammonium acetate ( $\mathrm{pH} 4.4)$ and acetonitrile was used as the mobile phase, the plate number was low. The mobile phase that showed the best tailing factor, resolution, and plate number was a $35: 65$ volume ratio of $0.01 \mathrm{~mol} / \mathrm{L}$ ammonium acetate (pH 4.4) and acetonitrile.

The wavelength that showed maximum absorbance for pramipexole dihydrochloride monohydrate in the UV spectrophotometry, $263 \mathrm{~nm}$, was tested in the HPLC method. It was concluded that the maximum absorbance wavelength in the HPLC method for pramipexole dihydrochloride monohydrate and the internal standard (tamsulosin $\mathrm{HCl}$ ) was also $263 \mathrm{~nm}$. To show the robustness of this method, first the mobile phase flow rate was changed $(1 \pm 0.2 \mathrm{~mL} / \mathrm{min})$, and later the $\mathrm{pH}$ of the mobile phase was changed ( $\mathrm{pH} 4.4 \pm 0.05)$.

During the development of the spectrophotometric method, the appropriate diluent was chosen. It was proven that the maximum absorbance wavelength of the chosen diluent was $263 \mathrm{~nm}$. In the first derivative spectrophotometric technique, recovery was found to be high and the RSD value was found to be low at the maximum absorbance levels observed (249 $\mathrm{nm}$ and $280 \mathrm{~nm})$

\section{Preparation of standard and sample solutions}

\section{Preparation of internal standard, standard stock, and} standard solutions for the HPLC method

Using water as a solvent, the internal standard solution of tamsulosin $\mathrm{HCl}$ was prepared at a concentration of $100.0 \mu \mathrm{g} / \mathrm{mL}$. The standard stock solution $(250.0 \mu \mathrm{g} / \mathrm{mL})$ was prepared from the internal standard solution. In order to construct a calibration curve, pramipexole dihydrochloride monohydrate standards were prepared from the standard stock solution in the concentration range $10.0-30.0 \mu \mathrm{g} / \mathrm{mL}$, using the internal standard solution as a solvent.

\section{Preparation of solution for spectrophotometric method}

The standard stock solution of $1000 \mu \mathrm{g} / \mathrm{mL}$ was prepared by dissolving $50 \mathrm{mg}$ pramipexole dihydrochloride monohydrate in $50 \mathrm{~mL}$ of $0.1 \mathrm{~mol} / \mathrm{L} \mathrm{HCl}$. From the stock solution, seven different concentrations were prepared in $100 \mathrm{~mL}$ volumetric flasks, at a concentration range of 5.0-35.0 $\mu \mathrm{g} / \mathrm{mL}$, using $0.1 \mathrm{~mol} / \mathrm{L} \mathrm{HCl}$ as a diluent. The calibration curves were created from these seven solutions. The absorbance of the standard solutions were recorded against a blank sample of $0.1 \mathrm{~mol} / \mathrm{L} \mathrm{HCl}$. After recording the zero order spectra, the first derivatives of the above absorption spectra were determined and recorded.

\section{Sample preparation}

Twenty tablets containing pramipexole dihydrochloride monohydrate were precisely weighed and ground into a fine powder. For the HPLC method, a quantity of the powder equivalent to one tablet weight was transferred to a $50 \mathrm{~mL}$ volumetric flask containing the internal standard solution and stirred for $20 \mathrm{~min}$ with a magnetic stirrer. In the spectrophotometric method, a quantity of the powder equivalent to one tablet was transferred into a $50 \mathrm{~mL}$ volumetric flask containing $0.1 \mathrm{~mol} / \mathrm{L} \mathrm{HCl}$. Prepared solutions were filtered through a $0.20 \mu \mathrm{m}$ membrane filter and the filtered liquid was subsequently used for the tests. Quantification was achieved by means of the calibration curve method, which was established using the calibration results.

\section{Validation of the analytical methods}

The described HPLC and spectrophotometric methods have been validated according to $\mathrm{ICH}(\mathrm{Q} 2 \mathrm{~B}$, 1996) and FDA (2000) guidelines. 


\section{Robustness}

The robustness of the method was determined by varying the $\mathrm{pH}$ from 4.35 to 4.45 and the flow rate from 0.8 to $1.2 \mathrm{~mL} / \mathrm{min}$. Moreover, the stability of the prepared standard solution and sample solutions, including the placebo and pramipexole dihydrochloride monohydrate at the concentration of $20.0 \mu \mathrm{g} / \mathrm{mL}$ was evaluated via analysis after 3, 6, 12, 24 and 48 hours.

\section{Selectivity and specificity}

In order to determine the specificity of both methods, $1.0 \mathrm{mg}$ pramipexole dihydrochloride monohydrate was added to the placebo, which contained $42.0 \mathrm{mg}$ of each excipient found in the tablet form. These excipients are mannitol, colloidal silicone dioxide, corn starch, Polyvidone K25, and magnesium stearate. All precisely weighed components were transferred into volumetric flasks and dissolved by shaking with internal standard and $0.1 \mathrm{~mol} / \mathrm{L} \mathrm{HCl}$ and the solutions were filled up to the volume mark with diluent. After dilution, solutions were filtered through a $0.20 \mu \mathrm{m}$ membrane filter and analyzed in both methods under specified conditions.

\section{Linearity of calibration and limits of detection and quantification}

To test the linearity, five different concentration levels ranging from $10.0-30.0 \mu \mathrm{g} / \mathrm{mL}$ for the HPLC method and seven different concentrations of standard solutions from $5.0-35.0 \mu \mathrm{g} / \mathrm{mL}$ for the spectrophotometric method were used in order to construct calibration curves. For both methods, solutions were prepared in triplicate. In the HPLC method, a calibration curve was constructed using the least squares method by plotting the peak area ratios versus concentration of pramipexole dihydrochloride monohydrate and the linear regression equation was used to determine linearity. Under defined chromatographic conditions, the detector response for the peak area ratio of pramipexole dihydrochloride monohydrate to tamsulosin $\mathrm{HCl}$ (IS) in the HPLC studies was observed and it was shown that the calculated ratio was proportional to pramipexole dihydrochloride monohydrate concentration. Linear regression analysis was performed in order to determine the correlation coefficients. In the spectrophotometric method, a calibration curve was constructed using the least squares method by plotting the derivative absorbances versus the concentration of pramipexole dihydrochloride monohydrate for the first derivative of the spectra. The limit of detection (LOD) is defined as the lowest amount of analyte in a sample that can be detected but not necessarily quantified to an exact value. The limit of quantification is the lowest amount of substance that can be quantified precisely and accurately. For both methods, the LOD (detection limit) and LOQ (quantification limit) were calculated based on the response and slope of the regression equation.

\section{Precision}

For the precision of the HPLC method, pramipexole dihydrochloride monohydrate standard solutions were evaluated six times at specified intervals (time $=0,30$ th minute, $1 \mathrm{st}, 2 \mathrm{nd}$, 5th and 10th hour) in order to achieve repeatability in the same day (intra-day precision). For inter-day precision, the solutions were tested on 3 different days, 3 times each day, in order to achieve inter-day precision.

The precision of the spectrophotometric method was determined by pramipexole dihydrochloride monohydrate standard solutions which were tested at five specified intervals (time $=0,1 \mathrm{st}, 2 \mathrm{nd}, 3 \mathrm{rd}$ and 4 th hour) in order to achieve repeatability in the same day (intra-day precision). The solutions were also tested on 4 different days, 3 times each day, for inter-day precision in order to achieve reproducibility.

\section{Accuracy}

For both methods, accuracy was investigated by the determination of the drug substance (active substance) in the presence of various excipients like mannitol, colloidal silicone dioxide, corn starch, Polyvidone K25 and magnesium stearate. In the HPLC method, samples are prepared by mixing the same amount of placebo mixture ( $840 \mathrm{mg}$ ) with 5 different amounts (between $50-150 \%$ ) of the active substance. The sample solutions were injected under specified conditions and peak area ratios were recorded. In the spectrophotometric method, accuracy was analyzed by using the same amount of placebo mixture ( $420 \mathrm{mg}$ ) with 3 different amounts (between 25-175\%) of active substance.

The procedures above were repeated three times.

\section{RESULTS AND DISCUSSION}

In this paper, two newly developed techniques (using HPLC and spectrophotometric methods) were proposed for pramipexole dihydrochloride monohydrate assay in pharmaceutical dosage forms. 


\section{Optimization of the chromatographic conditions}

To optimize the proposed HPLC method, all of the experimental conditions were investigated. For this purpose the following mobile phases were tried: 1 ) ammonium acetate: acetonitrile $(25: 75$, by volume $) ; 2)$ ammonium acetate: acetonitrile (35:65, by volume); and 3 ) ammonium acetate: acetonitrile (50:50, by volume), at a flow rate of $1.0 \mathrm{~mL} / \mathrm{min}$. The best resolution was achieved when using a mobile phase consisting of ammonium acetate: acetonitrile (35:65, by volume). The results obtained regarding the variation in mobile phase ratios are shown below in Table I. The stationary phases RP-Select B, RP-8, C8, and C18 were used. The optimum chromatographic performance was achieved when using Merck LiChrospher 60 RP-Select B 125 x 4.0 mm, $5 \mu \mathrm{m}$ (Figures $2 \mathrm{a}, 2 \mathrm{~b}$ ). The other stationary phases were found to be ineffective for the determination of system suitability

TABLE I - System suitability parameters for the quantification of pramipexole in tablets by HPLC

\begin{tabular}{lcccccc}
\hline Variations & $\begin{array}{c}\text { Pramipexole/IS } \\
\text { Retention Time }\end{array}$ & $\begin{array}{c}\text { Pramipexole/IS } \\
\text { Area/Ratio }\end{array}$ & Retention Factor & Tailing Factor & Plate Number & Resolution \\
\hline $\begin{array}{l}\text { Mobile Phase } \\
(25: 75, \mathrm{v} / \mathrm{v})\end{array}$ & $2.63 / 3.07$ & 0.87 & 4.26 & 1.46 & 2497 & 2.03 \\
\hline $\begin{array}{l}\text { Mobile Phase } \\
\left(\begin{array}{l}35: 65, \mathrm{v} / \mathrm{v}) \\
(\text { Original })\end{array}\right.\end{array}$ & $2.07 / 3.05$ & 0.90 & 3.13 & 1.40 & 2071 & 4.87 \\
\hline $\begin{array}{l}\text { Mobile } \text { Phase } \\
(50: 50, \mathrm{v} / \mathrm{v})\end{array}$ & $1.77 / 3.86$ & 0.83 & 2.54 & 1.36 & 1145 & 7.87 \\
\hline
\end{tabular}

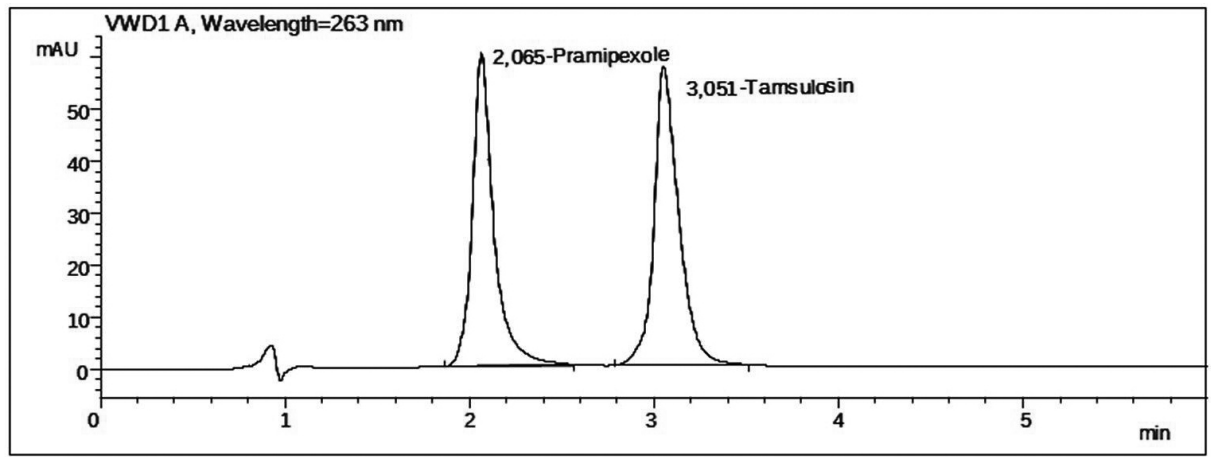

FIGURE 2A - Chromatogram of pramipexole dihydrochloride monohydrate $(20.0 \mu \mathrm{g} / \mathrm{mL})$ with tamsulosin $\mathrm{HCl}(100.0 \mu \mathrm{g} / \mathrm{mL})$ as the internal standard.

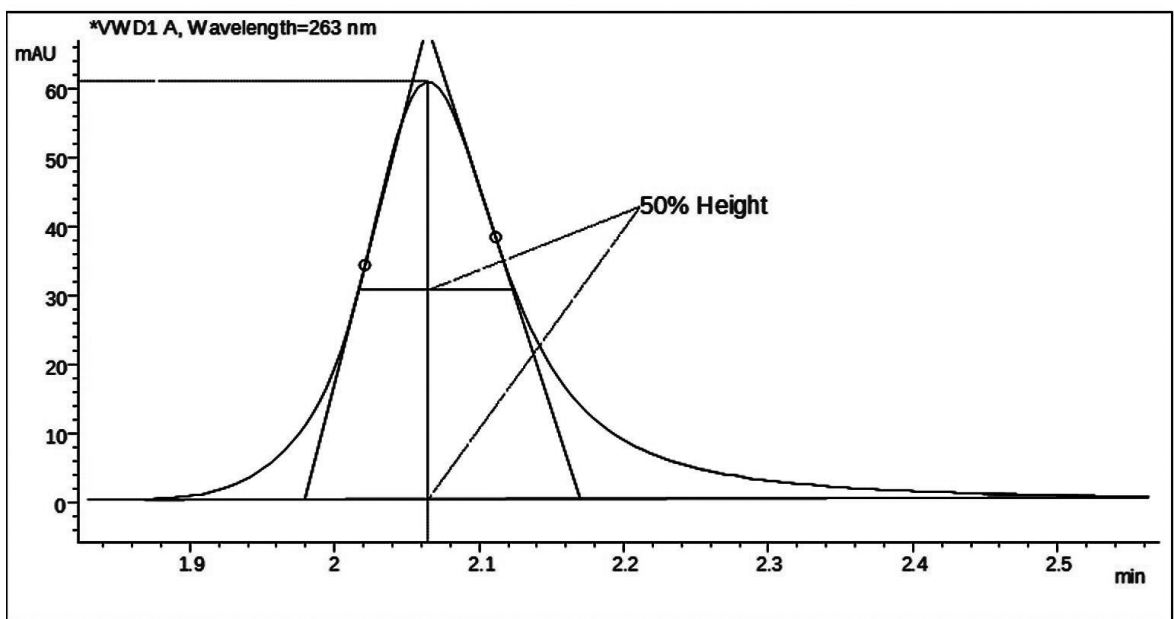

FIGURE 2B - Peak performance evaluation of pramipexole dihydrochloride monohydrate. 
parameters, as symmetrical and uniform peaks could not be obtained.

The robustness of the proposed method was evaluated by varying the $\mathrm{pH}$ from 4.35 to 4.45 , which resulted in no effect on the chromatographic conditions. The mobile phase flow rate was changed between 0.8 and $1.2 \mathrm{~mL} / \mathrm{min}$. When the flow rate was lowered to 0.8 $\mathrm{mL}$, the retention time increased to 2.58 minutes, while increasing the flow rate to $1.2 \mathrm{~mL}$ decreased the retention time to 1.72 minutes. The results are presented in Table II.

According to studies, tamsulosin $\mathrm{HCl}$ is used as an internal standard because it gives a good response in experimental conditions and does not interfere with other peaks. The elution was monitored in the whole
UV spectrum to determine the optimum selectivity and detectivity. The results indicated that the wavelength of $263 \mathrm{~nm}$ should be selected for the detection of pramipexole dihydrochloride monohydrate and tamsulosin $\mathrm{HCl}$ (IS) since it demonstrated the greatest response in the experiment.

The stability of standard stock solutions and sample standard solutions were also assessed. The results show that, over a $48 \mathrm{~h}$ period at room temperature $\left(30^{\circ} \mathrm{C}\right)$, the change in quantity of pramipexole dihydrochloride monohydrate in the standard solution was $0.36 \%$ and the change in quantity of pramipexole dihydrochloride monohydrate in the sample solution that contains placebo was $0.17 \%$. These results are shown in Table III below.

TABLE II - Results of robustness test of the HPLC method (variation of the $\mathrm{pH}$ and flow rate of the mobile phase)

\begin{tabular}{lcccccc}
\hline Variations & $\begin{array}{c}\text { Pramipexole } \\
\text { Retention Time }\end{array}$ & $\begin{array}{c}\text { Pramipexole/IS } \\
\text { Area/Ratio }\end{array}$ & $\begin{array}{c}\text { Retention } \\
\text { Factor }\end{array}$ & $\begin{array}{c}\text { Tailing } \\
\text { Factor }\end{array}$ & $\begin{array}{c}\text { Plate } \\
\text { Number }\end{array}$ & Resolution \\
\hline $\begin{array}{l}\text { Mobile Phase } \\
0.01 \mathrm{~mol} / \mathrm{L} \text { AA pH; } 4.35\end{array}$ & 1.96 & 0.94 & 2.91 & 1.30 & 2041 & 4.92 \\
\hline $\begin{array}{l}\text { Mobile Phase } \\
\begin{array}{l}0.01 \mathrm{~mol} / \mathrm{L} \text { AA pH; } 4.40 \\
\text { (Original) }\end{array}\end{array}$ & 1.96 & 0.93 & 2.92 & 1.31 & 2047 & 4.95 \\
\hline $\begin{array}{l}\text { Mobile Phase } \\
0.01 \mathrm{~mol} / \mathrm{L} \text { AA pH; } 4.45\end{array}$ & 1.96 & 0.92 & 2.92 & 1.31 & 2052 & 4.87 \\
\hline $\begin{array}{l}\text { Mobile Phase } \\
\text { Flow Rate: } 0.8 \mathrm{~L} / \mathrm{min}\end{array}$ & 2.58 & 0.94 & 4.15 & 1.39 & 2142 & 5.43 \\
\hline $\begin{array}{l}\text { Mobile Phase } \\
\text { Flow Rate: } 1.0 \mathrm{~mL} / \mathrm{min} \\
\text { (Original) }\end{array}$ & 2.06 & 0.94 & 3.12 & 1.36 & 2043 & 5.25 \\
\hline $\begin{array}{l}\text { Mobile Phase } \\
\text { Flow Rate: } 1.2 \mathrm{~L} / \mathrm{min}\end{array}$ & 1.72 & 0.94 & 2.43 & 1.33 & 1674 & 4.99 \\
\hline
\end{tabular}

TABLE III - Results of robustness test of the HPLC method (solution stability)

\begin{tabular}{lcccccccc}
\hline & $\begin{array}{c}\text { STANDARD } \\
\text { Pramipexole } \\
\text { Area (mAU) }\end{array}$ & \% Change & $\begin{array}{c}\text { STANDARD } \\
\text { IS Area } \\
\text { (mAU) }\end{array}$ & \% Change & $\begin{array}{c}\text { SAMPLE } \\
\text { Pramipexole } \\
\text { Area (mAU) }\end{array}$ & \% Change & $\begin{array}{c}\text { SAMPLE } \\
\text { IS Area } \\
\text { (mAU) }\end{array}$ & \% Change \\
\hline Time $=0$ & 499.3 & - & 529.6 & - & 515.3 & - & 544.6 & - \\
3rd hour & 498.2 & 0.22 & 530.5 & 0.17 & 514.7 & 0.12 & 544.4 & 0.04 \\
6th hour & 497.8 & 0.30 & 532.7 & 0.58 & 516.9 & 0.31 & 546.2 & 0.29 \\
12th hour & 497.4 & 0.38 & 529.9 & 0.06 & 514.9 & 0.08 & 544.2 & 0.07 \\
24th hour & 498.6 & 0.14 & 530.5 & 0.17 & 514.6 & 0.14 & 544.6 & 0.00 \\
48th hour & 497.5 & 0.36 & 530.8 & 0.23 & 514.4 & 0.17 & 544.7 & 0.02 \\
\hline Mean & $\mathbf{4 9 8 . 1}$ & & $\mathbf{5 3 0 . 6}$ & & $\mathbf{5 1 5 . 1}$ & & $\mathbf{5 4 4 . 8}$ & \\
Standard & $\mathbf{0 . 7 0}$ & & $\mathbf{1 . 0 9}$ & & $\mathbf{0 . 9 2}$ & & $\mathbf{0 . 7 1}$ & \\
$\begin{array}{l}\text { Deviation } \\
\text { (RSD\%) }\end{array}$ & $\mathbf{0 . 1 4}$ & & $\mathbf{0 . 2 0}$ & & $\mathbf{0 . 1 8}$ & & $\mathbf{0 . 1 3}$ \\
\hline
\end{tabular}


The specificity parameter of the HPLC method was analyzed to identify the interference of excipients by comparing the chromatograms of the drug substance and the most commonly used excipients mixture. The chromatograms obtained from the mixture containing the standard solution, and internal standard solutions from the placebo mixture and from the pharmaceutical product, are shown in Figures 3a, b, and c, respectively. As shown in Table IV, the results obtained exhibited no interference from excipients.

The precision of the HPLC method was determined by establishing the repeatability (intra-day) and reproducibility (inter-day) parameters of the pramipexole dihydrochloride monohydrate standard solutions. Moreover, injection repeatability was performed in order to confirm the performance of the HPLC method. The calculated RSD (relative standard deviation) values showed that the method exhibited good repeatability $(<0.77)$ for intra-day and inter-day precision. The results confirmed the high precision of the HPLC method.

For the development of a sensitive derivative spectrophotometric method, $0.1 \mathrm{~mol} / \mathrm{L} \mathrm{HCl}$ was selected as a solvent system due to its sensitivity, lack of interference, ease of preparation, suitability for drug content estimation, and cost. The direct UV spectrum and the first derivative spectrum of pramipexole dihydrochloride monohydrate in $0.1 \mathrm{~mol} / \mathrm{L} \mathrm{HCl}$ solution are shown in Figures $4 \mathrm{a}$ and $\mathrm{b}$, respectively. The derivative spectrophotometry technique was chosen for the determination of pramipexole dihydrochloride monohydrate since it could remove broadband contributions from excipients and overcome the interference caused by peak overlapping. Derivative spectra of different orders were studied for pramipexole

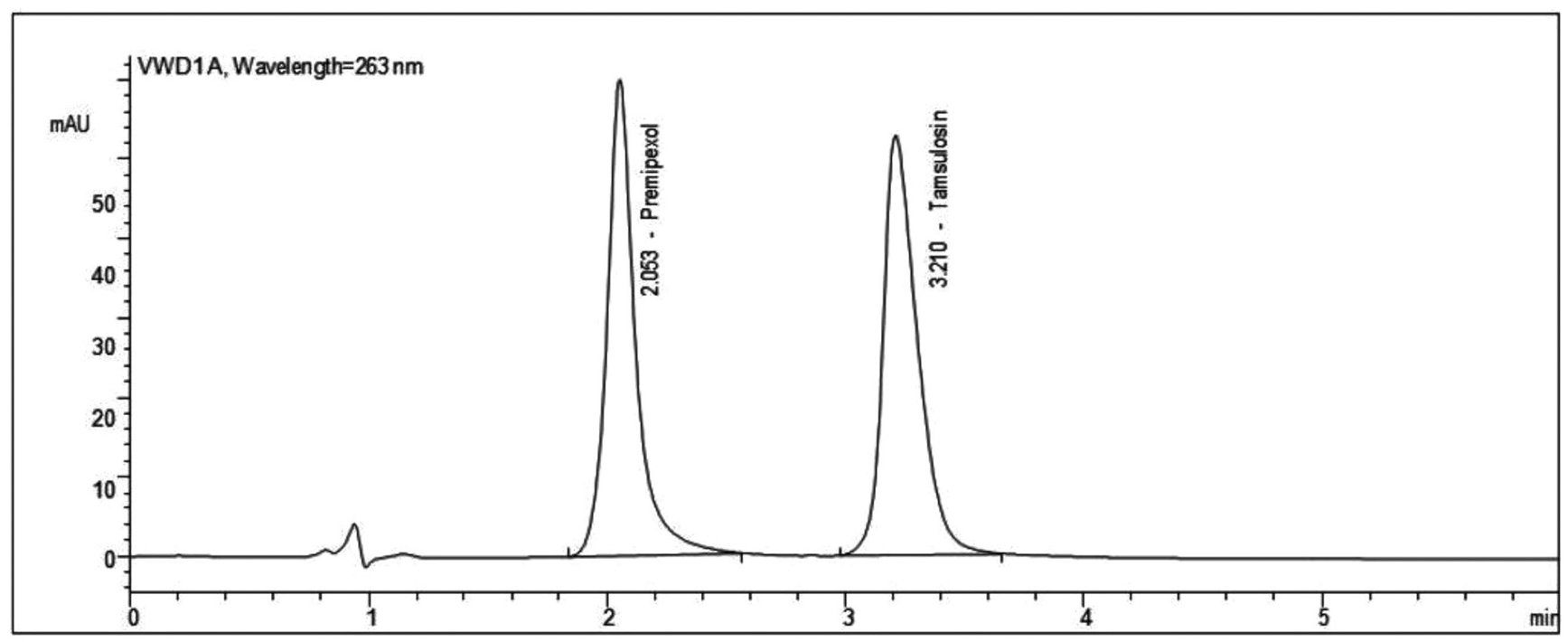

FIGURE 3A - Chromatogram of mixture containing pramipexole standard solution and internal standard solution.

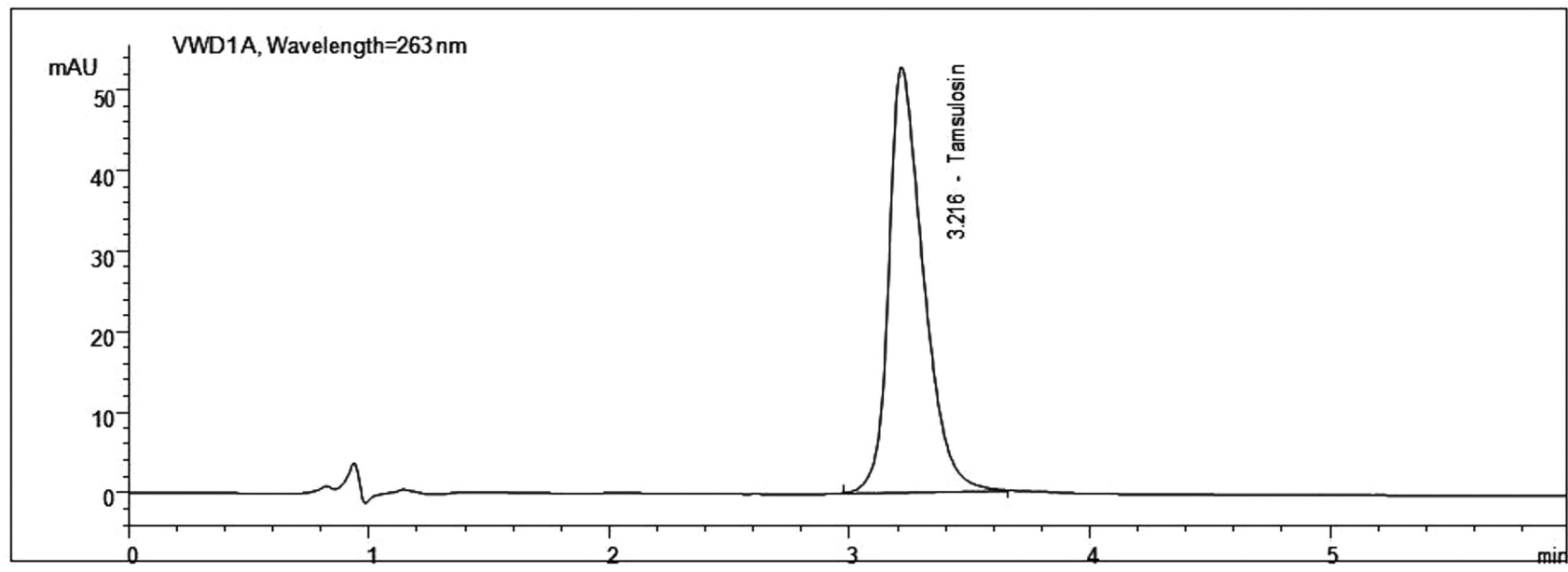

FIGURE 3B - Chromatogram of placebo mixture. 


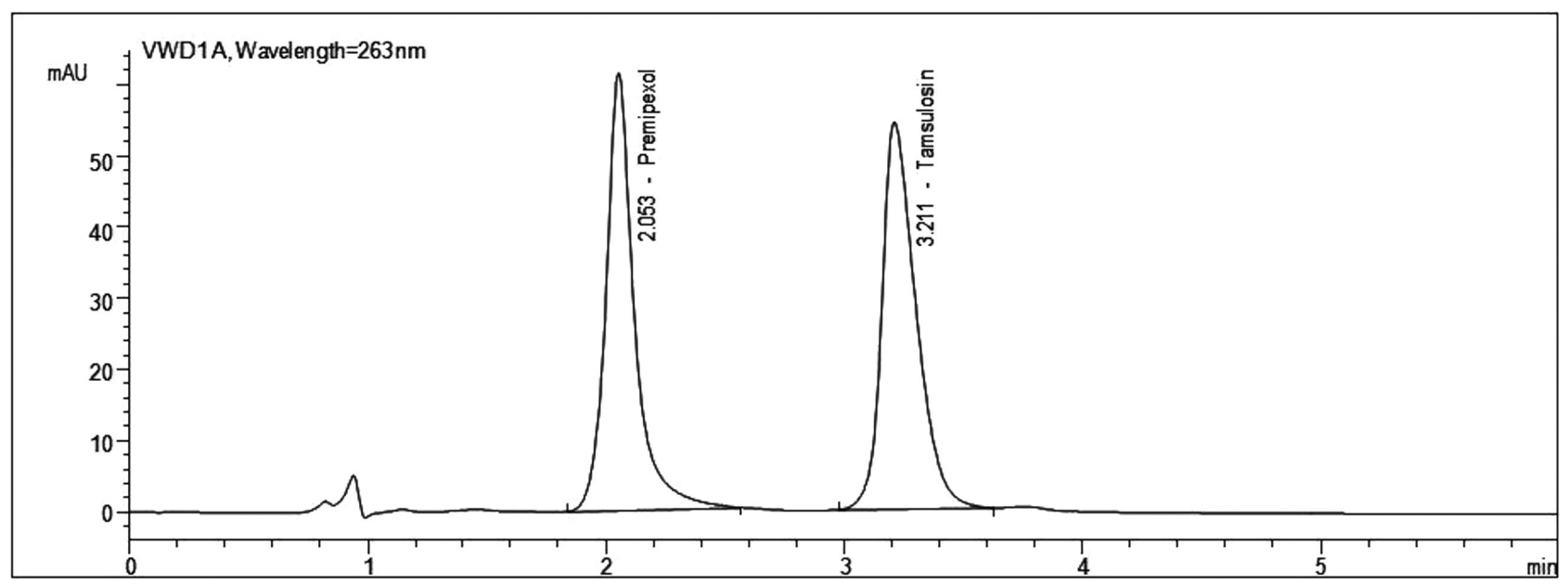

FIGURE 3C - Chromatogram of pharmaceutical product.

TABLE IV - Results of specificity test of the HPLC method

\begin{tabular}{lcccc}
\hline & $\begin{array}{c}\text { Pramipexole } \\
\text { Concentration } \\
(\mu \mathrm{g} / \mathrm{mL})\end{array}$ & $\begin{array}{c}\text { IS (Tamsulosin HCl) } \\
\text { Concentration } \\
(\mu \mathrm{g} / \mathrm{mL})\end{array}$ & $\begin{array}{c}\text { HPLC Retention } \\
\text { Time }\left(\mathrm{R}_{\mathrm{t}}\right) \text { Reading }\end{array}$ & $\begin{array}{c}\text { HPLC Area Value } \\
(\mathrm{mAU}) \text { Reading }\end{array}$ \\
\hline Mobile Phase & - & - & - & - \\
Internal Standard & - & 100 & 3.22 & 531.5 \\
Placebo & - & 100 & 3.22 & 529.2 \\
Pramipexole Working Standard & 20 & 100 & 2.05 & 500.5 \\
& & & 3.21 & 530.4 \\
Sample & 20 & 100 & 2.05 & 513.4 \\
\hline
\end{tabular}

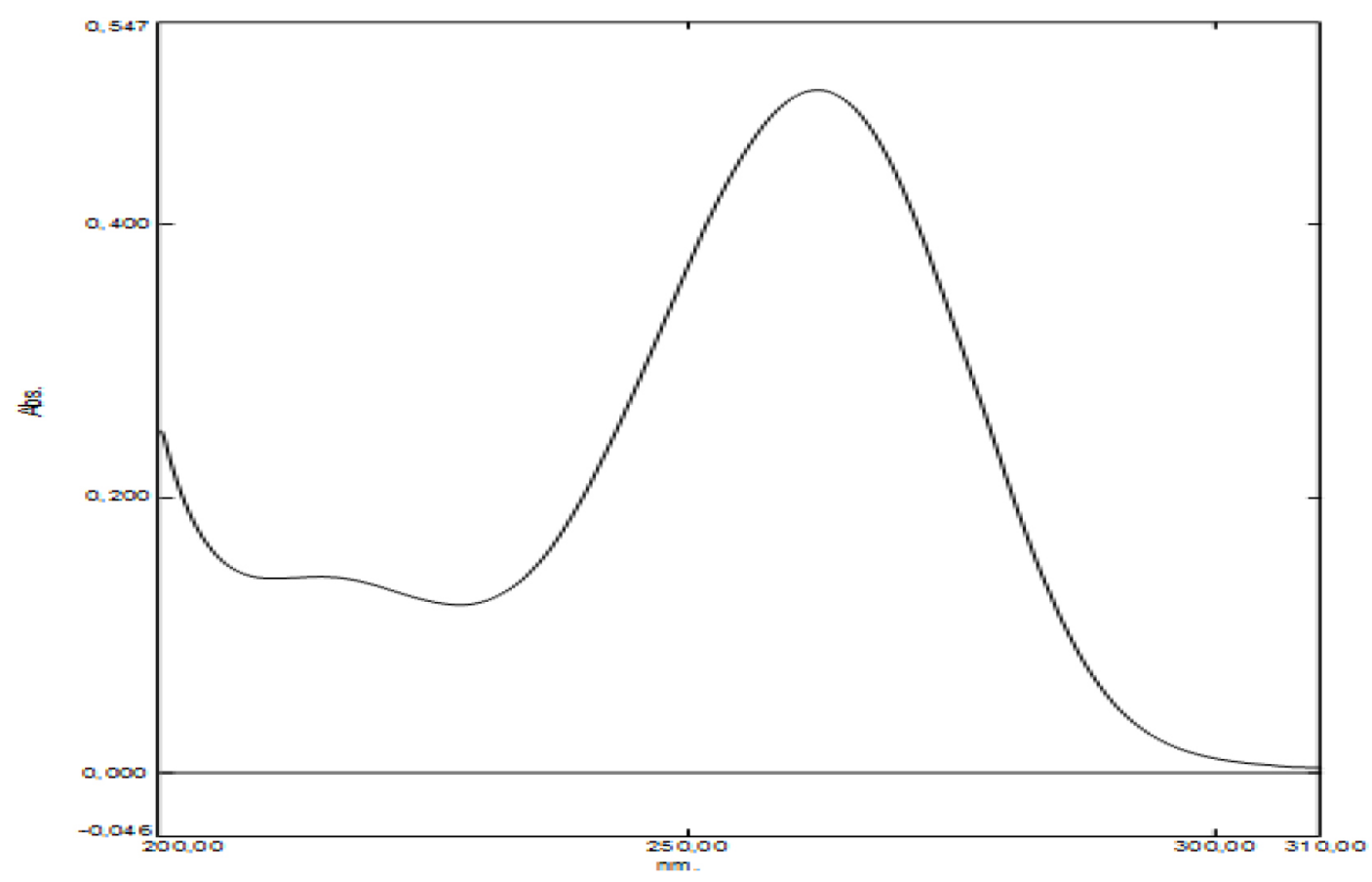

FIGURE 4A - Zero order UV scans pramipexole dihydrochloride monohydrate $(20.0 \mu \mathrm{g} / \mathrm{mL})$ in $0.1 \mathrm{~mol} / \mathrm{L} \mathrm{HCl}$. 


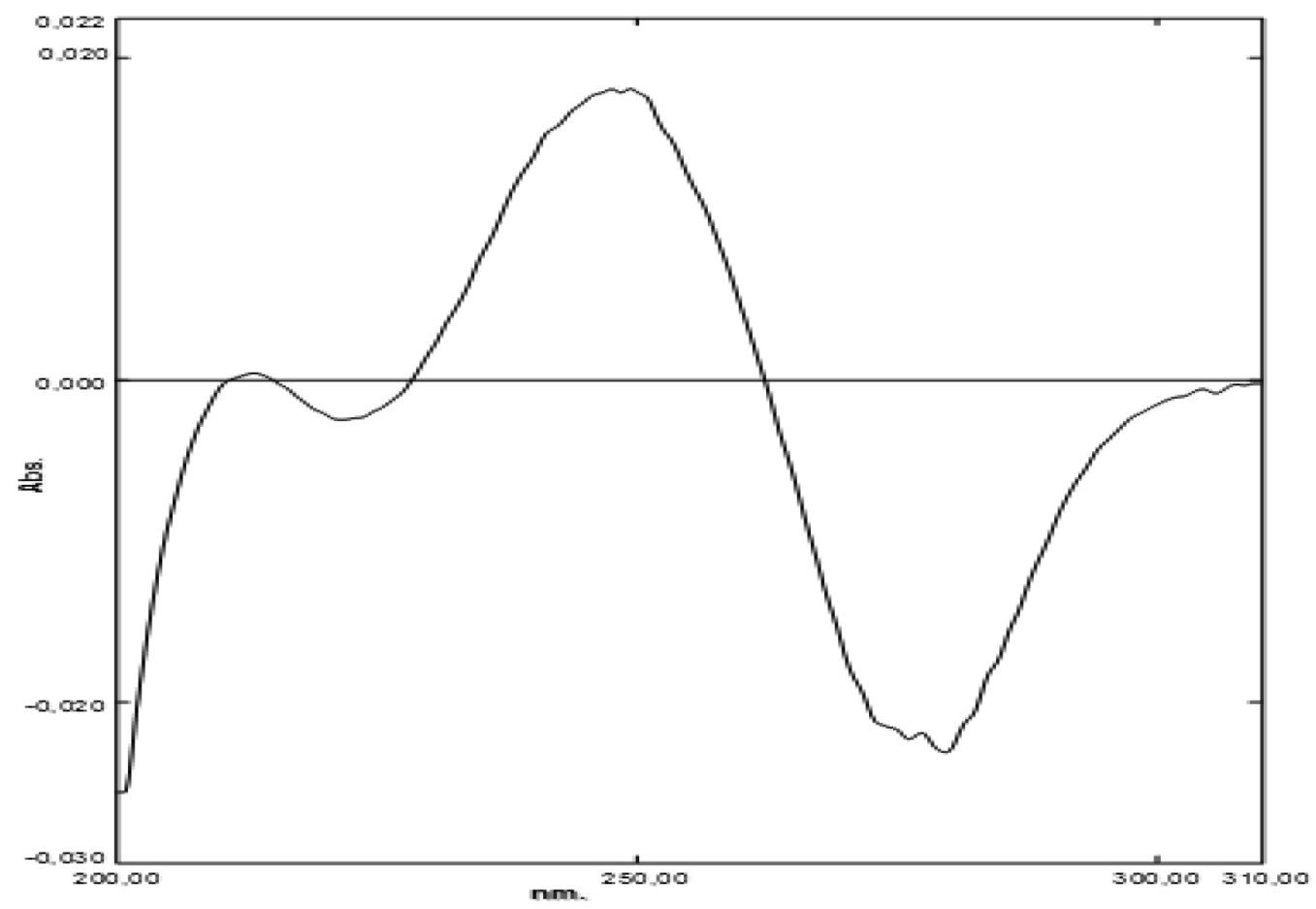

FIGURE 4B - First derivative spectra of pramipexole dihydrochloride monohydrate $(20.0 \mu \mathrm{g} / \mathrm{mL})$ in $0.1 \mathrm{~mol} / \mathrm{L} \mathrm{HCl}$.

dihydrochloride monohydrate and experimental results showed that the first derivative spectra gave well-defined peaks around 249 and $280 \mathrm{~nm}$, with suitable precision.

The first derivative method studies were evaluated and the precision parameter determined. The RSD (relative standard deviation) values were calculated and results indicated that the method demonstrated good repeatability $(<2.72)$ for intra-day and inter-day precision.

The specificity parameter of the first derivative spectrophotometric method was calculated to identify the interference from excipients by comparing the derivative spectra of the drug substance and the most commonly used excipient mixture. The resulting derivative spectra did not show any peak other than the standard solution, which demonstrated the specificity of the method. As shown in Table V, the results obtained showed no interference from excipients.

Assay performance of the present methods were evaluated by linearity, accuracy, precision, LOD, LOQ, stability and applicability in pharmaceutical dosage forms. The detector response for the peak area ratios of pramipexole dihydrochloride monohydrate to tamsulosin $\mathrm{HCl}$ (IS) in HPLC studies was observed under defined chromatographic conditions and it was recorded that the calculated ratio was proportional to pramipexole dihydrochloride monohydrate concentration. In addition, it was discovered that the signals recorded at around 249 and $280 \mathrm{~nm}$ with the first derivative spectra were proportional to pramipexole dihydrochloride monohydrate concentration. To obtain calibration curves for both proposed methods, chromatograms and spectra were recorded at varying concentrations of pramipexole dihydrochloride monohydrate. For each concentration, measurements were performed at least three times. The characteristics of the calibration curves are summarized in Table VI. Under the experimental conditions, the limit of detection (LOD) and the limit of quantification (LOQ) were calculated using $\mathrm{LOD}=3 \mathrm{~s} / \mathrm{m}$ and $\mathrm{LOQ}=10 \mathrm{~s} / \mathrm{m}$

TABLE V - Results of Specificity Test of the spectrophotometric method

\begin{tabular}{lccc}
\hline & Pramipexole & \multicolumn{2}{c}{ 1. DERIVATIVE } \\
\cline { 3 - 4 } & Concentration $(\mu \mathrm{g} / \mathrm{mL})$ & $249 \mathrm{~nm}$ & $280 \mathrm{~nm}$ \\
\hline Placebo & - & 0.000 & 0.000 \\
Pramipexole Working Standard & 20 & 0.020 & 0.026 \\
Sample & 20 & 0.020 & 0.026 \\
\hline
\end{tabular}


(Varma, Kaushal, Garg, 2004) to evaluate the sensitivity of the proposed methods.

The accuracy of both methods was assessed by adding known concentrations of pramipexole dihydrochloride monohydrate to sample solutions and then comparing the results of measured and calculated concentrations. The accuracy of the HPLC and first derivative spectrophotometric techniques was determined and expressed in terms of percent recovery. The mean recovery and RSD values obtained were found to be $100.5 \%$ and $1.10 \%$ for the HPLC technique and $<107.6 \%$ and $<4.36 \%$ for the first derivative spectrophotometric technique, respectively.

The proposed HPLC and first derivative spectrophotometric techniques were applied to the determination of pramipexole dihydrochloride monohydrate in the pharmaceutical product Pexola ${ }^{\circledR}$ Tablet $1.0 \mathrm{mg}$ (Batch No: 206377, Exp. Date: 08.2015, Manufacturer: Boehringer Ingelheim Pharma GmbH \& Co. KG., Germany).

The average weight, thickness, and diameter of 20 Pexola ${ }^{\circledR}$ Tablets were measured and the results were as follows; average weight $209 \mathrm{mg}$, average thickness 2.65 $\mathrm{mm}$, average diameter $9.08 \mathrm{~mm}$.
The results of the application of both the HPLC and the first derivative spectrophotometric methods for the quantitative analysis of pramipexole dihydrochloride monohydrate in Pexola ${ }^{\circledR}$ Tablet $1.0 \mathrm{mg}$ are given in Table VII. The results show that both methods can be successfully applied for the assay of pramipexole dihydrochloride monohydrate in pharmaceutical products. The parameters regarding the chromatographic and spectrophotometric methods developed are given in Table VIII.

The precision of analytical methods was determined using the pharmaceutical product for which the methods were developed. Sample solutions have been prepared with 20 tablets of Pexola ${ }^{\circledR}$ Tablet $1 \mathrm{mg}$ as described in the Experimental section. Prepared solutions were filtered through a $0.20 \mu \mathrm{m}$ membrane filter and the filtered liquid was used for the analysis of both methods.

\section{CONCLUSION}

The proposed methods to determine pramipexole dihydrochloride monohydrate quantities in pharmaceutical products were proven to be fast, precise, and simple. They produce results at a low cost and experience minimal

TABLE VI - Statistical analysis of calibration curves in the determination of pramipexole dihydrochloride monohydrate by HPLC and first derivative spectrophotometry

\begin{tabular}{lccc}
\hline Method & HPLC & \multicolumn{2}{c}{ First derivative spectrophotometry } \\
\hline Wavelength, $\mathrm{nm}$ & 263 & 249 & 280 \\
Linearity range $(\mu \mathrm{g} / \mathrm{mL})$ & $10-30$ & $5-35$ & $5-35$ \\
Slope & 4.74 & 0.94 & 1.29 \\
Intercept & $5.6 \times 10^{-4}$ & $2.0 \times 10^{-4}$ & $1.2 \times 10^{-3}$ \\
Correlation coefficient, $\mathrm{R}^{2}$ & 0.9997 & 0.9911 & 0.9971 \\
LOD $(\mathrm{ng} / \mathrm{mL})$ & 8 & 2.0 & 1.5 \\
LOQ $(\mathrm{ng} / \mathrm{mL})$ & 50 & 6.1 & 4.5 \\
\hline
\end{tabular}

TABLE VII - Results of the HPLC and first derivative spectrophotometry for the estimation of pramipexole dihydrochloride monohydrate in Pexola ${ }^{\circledR}$ Tablet $1.0 \mathrm{mg}$

\begin{tabular}{lccc}
\hline & HPLC & \multicolumn{2}{c}{ First derivative spectrophotometry } \\
\cline { 2 - 4 } & $263 \mathrm{~nm}(\%)$ & $249 \mathrm{~nm}(\%)$ & $280 \mathrm{~nm}(\%)$ \\
\hline Sample 1 & 99.4 & 107.4 & 101.9 \\
Sample 2 & 99.3 & 107.4 & 101.9 \\
Sample 3 & 99.3 & 107.4 & 101.9 \\
Sample 4 & 97.6 & 107.4 & 101.9 \\
Sample 5 & 100.2 & 107.4 & 101.9 \\
\hline Mean \% & 99.2 & 107.4 & 0.00 \\
S.D. & 0.97 & 0.00 & 0.00 \\
R.S.D \% & 0.97 & 0.00 & \\
\hline
\end{tabular}


TABLE VIII - The comparison of the parameters of the chromatographic and spectrophotometric methods developed for the determination of pramipexole dihydrochloride monohydrate

\begin{tabular}{|c|c|c|c|}
\hline Method & HPLC & Method & UV Spectrophotometry \\
\hline Device & Agilent HPLC 1200 & Device & Shimadzu UV-1601 \\
\hline Detector & UV & Detector & UV \\
\hline Column & $\begin{array}{c}\text { LiChrospher } 60 \text { RP Select B } \\
125 \times 4.0 \mathrm{~mm}, 5 \mu \mathrm{m}\end{array}$ & - & - \\
\hline Wavelength & $263 \mathrm{~nm}$ & Wavelength & $263 \mathrm{~nm}$ \\
\hline Flow rate & $1 \mathrm{~mL} / \mathrm{min}$ & 1.Derivative & $249 \mathrm{~nm}, 280 \mathrm{~nm}$ \\
\hline Injection volume & $20 \mu \mathrm{L}$ & - & - \\
\hline Column Temperature & $25^{\circ} \mathrm{C}$ & - & - \\
\hline Mobile phase & $\begin{array}{c}\text { 0.01 M Ammonium acetate } \\
(\mathrm{pH} 4.4) \text { : acetonitrile }(35: 65 \\
\mathrm{v} / \mathrm{v})\end{array}$ & - & - \\
\hline Solvent & $\begin{array}{l}\text { ISTD Solution }(100.0 \mu \mathrm{g} / \mathrm{mL} \\
\text { tamsulosin } \mathrm{HCl} \text { in Water })\end{array}$ & Solvent & $0.1 \mathrm{M} \mathrm{HCl}$ \\
\hline Calibration curves & $\begin{array}{l}\text { (10.0-30.0) } \mu \mathrm{g} / \mathrm{mL} / \text { solvent } \\
\text { (five solutions) }\end{array}$ & Calibration Curves & $\begin{array}{l}\text { (5.0-35.0) } \mu \mathrm{g} / \mathrm{mL} \text { solvent } \\
\text { (seven solutions) }\end{array}$ \\
\hline Standard solution & $20.0 \mu \mathrm{g} / \mathrm{m} /$ solvent & Standard Solution & $20.0 \mu \mathrm{g} / \mathrm{mL} /$ solvent \\
\hline Sample solution & 1 Tablet $/ 50 \mathrm{~mL}$ of solvent & Sample Solution & 1 Tablet $/ 50 \mathrm{~mL}$ of solvent \\
\hline Analysis time & 6 minute & Analysis Time & 1 minute \\
\hline
\end{tabular}

interference from drug excipients. The procedures, and their application to pharmaceutical forms of pramipexole dihydrochloride monohydrate, represent a good alternative in routine laboratorial analyses. Either procedure could be used for this determination, depending on the availability of the necessary instrumentation.

\section{REFERENCES}

ARMAĞAN, Ö. Spectrophotometric and spectrofluorimetric determination of some drugs containing secondary amino group in bulk drug and dosage forms via derivatization with 7-chloro-4-nitrobenzofurazon. Quim. Nova, v.34, n.4, p.677-682, 2011.

BABU, G.S.; RAJU, C.A.I. Spectrophotometric determination of pramipexole dihydrochloride monohydrate. Asian $J$. Chem., v.19, n.1, p.816-818, 2007.

CHANG-HAI, L.; QING-YAN, S.; CHUN-QUAN, S.; HAI, Z.; JUN, C.; LIANG, Z.; YI-FENG, C. Capillary electrophoresis for analysis of optical impurity of L-pramipexole. AJSMMU, v.30, n.9, p.1058-1061, 2009.
EL-BAYOUMI, A.E.; BADAWY, A.M.; KAFOU, A.; ELGHASEM, H. Stability-indicating spectrophotometric, densitometric and HPLC methods for determination of pramipexole in dosage forms. $B-F O P C U$, v.47, n.3, p.111, 2009.

EL-SHERIF, Z.A.; ABDEL-FATTAH, L.S.; EL-HOUSSINI, O.M. Micro determination of pramipexole dihydrochloride in bulk powder and in tablets. $B-F O P C U$, v. $46, \mathrm{n} .3$, p.1-13, 2008.

Guidance for Industry. Analytical Procedures and Methods Validation, 2000. Available at: <http://www.fda.gov/ downloads/Drugs/GuidanceComplianceRegulatoryInfor mation/Guidances/UCM070489.pdf>. Accessed on: June 2013.

GURUPADAYYA, B.M.; VISHWAJITH, V.; SRUJANA, N. Spectrophotometric methods for the estimation of pramipexole dihydrochloride in pharmaceutical formulations. World J. Chem., v.4, n.2, p.157-160, 2009.

HUA, L.; XIAOYAN, C.; XIAOJIN, S.; YAN, Z.; MINGKANG Z.; ZHONGDONG, L.; DAFANG, Z. LC-MS/MS determination of pramipexole in human plasma. YaowuFenxi-Zazhi, v.31, n.2, p.330-335, 2011. 
INTERNATIONAL CONFERENCE ON HARMONISATION. ICH. $Q 2 B$ : Validation of Analytical Procedures: Methodology, Step 4. ICH, 1996. Available at: <http:// www.ich.org/fileadmin/Public_Web_Site/ICH_Products/ Guidelines/Quality/Q2_R1/Step4/Q2_R1_Guideline. pdf $>$. Accessed on: July 2012.

JANCIC, B.; MEDENICA, M.; IVANOVIC, D.; MALENOVIC, A. Chromatographic determination of dissociation constants of pramipexole and its impurities. Chromatographia, v.65, n.9/10, p.633-635, 2007a.

JANCIC, B.; MEDENICA, M.; IVANOVIC, D.; MALENOVIC, A. Experimental design in chromatographic analysis of pramipexole and its impurities. Acta. Chim. Slov., v.54, n.1, p.49-54, 2007b.

KAMIENSKA-DUDA, A.; KOSMACINSKA, B. Determination of chromatographic purity of pramipexole dihydrochloride monohydrate - methods comparison. Przem. Chem., v.87, n.7, p.796-799, 2008.

MALENOVIC, A.; JANCIC, B.; VEMIC, A.; DARKO, I.; MEDENICA, M. Validation of a column liquid chromatographic method for the analysis of pramipexole and its 5 impurities. J AOAC Int., v.93, n.4, p.1102-1112, 2010.

MANISH, Y.; RAJASEKHAR, R.; HERMAL, K.; JAYSUKH, R.; RAKESH, P.; PURAN S.; SHRIVASTAV P.S. Validated ultra-performance liquid chromatography tandem mass spectrometry method for the determination of pramipexole in human plasma. J. Chromatogr. Sci., v.48, n.10, p.811$818,2010$.

MUSENGA, A.; ERNST, K.; EMANUELE, M.; RASI, F.; RAGGI, M.A. Analysis of the anti-Parkinson drug pramipexole in human urine by capillary electrophoresis with laser-induced fluorescence detection. Anal. Chim. Acta, v.626, n.1, p.89-96, 2008.

O’NEIL, M.J.; HECKELMAN, P.E.; KOCH, C.B.; KRISTIN, J.R. The merck index. 14.ed. White House Station, NJ: Merck and Co. Inc, 2006. 7705 p.

PANCHAL, J.G.; PATEL, R.V.; MENON, S.K. Development and validation of GC/MS method for determination of pramipexole in rat plasma. Biomed Chromatogr, v.25, n.4, p.524-530, 2011.
PHYSICIANS' DESK REFERENCE®. Pramipexole dihydrochloride full prescribing information. Available at: <http://www.pdr.net/drug-information/ mirapex?druglabelid=1745>. Accessed on: April 2013.

RAMAKRISHNA, N.V.S.; VISHWOTTAM, K.; WISHU, S.; KOTESHWARA, M.; SANTOSH, M.; DEVENDER, A. Quantification of pramipexole in human plasma by liquid chromatography tandem mass spectrometry using tamsulosin as internal standard. Biomed. Chromatogr., v.21, n.11, p.1151-1158, 2007.

RANI, B.S.; REDDY, P.V. New spectrophotometric methods for the determination of Ppramipexole in bulk and pharmaceutical dosage forms. Acta. Ciênc. Indica Chem., v.33, n.1, p.9-11. 2007.

RANI, B.S.; REDDY, P.V. New spectrophotometric methods for the determination of pramipexole in pharmaceutical dosage forms, Acta Ciênc. Indica Chem., v.32, n.4, p.317320, 2006.

RAO, S.; KUMAR, D.A.; MASTANAMMA, S.; SRILAKSHMI, K. Estimation of pramipexole by an RP-HPLC method. $J$. Chem. Sci., v.7, n.4, p.2789-2794, 2009.

SHUHUI, M. High performance liquid chromatography (HPLC) method for analyzing and separating pramipexole dihydrochloride and optical isomer thereof. CN Pat. $101769902,2010$.

SRINUBABU, G.; JAGANBABU, K.; SUDHARANI, B.; VENUGOPAL, K.; GIRIZASANKAR, G.; RAO, J.V.L.N.S. Development and validation of a LC method for the determination of pramipexole using an experimental design, Chromatographia, v.64, n.1-2, p.95-100, 2006.

SYEDA, H.; AKALANKA, D.; APPALA, R.S.; SYED S. Gradient Ultra Fast Liquid Chromatographic analysis of and its application to drug quality control. Pharm. Lettre, v.2, n. 4, p.315-325, 2010.

THANGABALAN, B.; KUMAR, P.; LAVANYA, G.; INTHIAZ, S.; DEEPTHI, C.; MANOHAR, B.S.; KUMAR, P.V. Extractive spectrophotometric determination of pramipexole dihydrochloride in pure and pharmaceutical formulations. JPR, v.4, n.3, p.813-814, 2011a. 
THANGABALAN, B.; VAMSI, K.M.; RAVITEJA, N.V.R.; HAJERA, B.S.K.; MANOHAR, B.S.; KUMAR, V.P. Spectrophotometric methods for the determination of pramipexole dihydrochloride in pure and in pharmaceutical formulations. J. Pharm. Pharm. Sci., v.3, p.84-85, 2011 b.

VARMA, M.V.S.; KAUSHAL, A.M.; GARG, S. Rapid and selective UV spectrophotometric and RP-HPLC methods for dissolution studies of Oxybutynin immediate release and controlled release formulations. J. Pharm. Biomed. Anal., v.36, n.3, p.669-674, 2004.
VIJAYA, B.D.; KUMAR, H.K.; VIDYA, S.P.V.; KUMAR, S.S.; NAIDU, A; RAMESH, M. Development and validation of a sensitive LC-MS/MS method with electrospray ionization for quantitation of pramipexole in human plasma: application to a clinical pharmacokinetic study. Biomed Chromatogr., v.23, n.2, p.212-218, 2009.

Received for publication on $02^{\text {nd }}$ November 2014 Accepted for publication on $17^{\text {th }}$ September 2015 
